\title{
Seasonal Variation in the Gonadotropin-Releasing Hormone Response to Kisspeptin in Sheep: Possible Kisspeptin Regulation of the Kisspeptin Receptor
}

\author{
Qun Li Alexandra Roa lain J. Clarke Jeremy T. Smith
}

Department of Physiology, Monash University, Melbourne, Vic., Australia

\section{Key Words}

Kisspeptin - KiSS-1 • Gonadotropin-releasing hormone •

Preovulatory surge

\begin{abstract}
Kisspeptin signaling in the hypothalamus appears critical for the onset of puberty and driving the reproductive axis. In sheep, reproduction is seasonal, being activated by short days and inhibited by long days. During the non-breeding (anestrous) season, gonadotropin-releasing hormone $(\mathrm{GnRH})$ and gonadotropin secretion is reduced, as is the expression of Kiss1 mRNA in the brain. Conversely, the luteinizing hormone response to kisspeptin during this time is greater. To determine whether the $\mathrm{GnRH}$ response to kisspeptin is increased during anestrus, we utilized hypophysial portal blood sampling. In anestrus ewes, the $\mathrm{GnRH}$ and $\mathrm{LH}$ responses to kisspeptin were greater compared to the breeding season (luteal phase). To ascertain whether this difference reflects a change in Kiss1r, we measured its expression on GnRH neurons using in situ hybridization. The level of Kiss1r was greater during the non-breeding season compared to the breeding season. To further examine the mechanism underlying this change in Kiss1r, we examined Kiss1r/ $\mathrm{GnRH}$ expression in ovariectomized ewes (controlling for sex steroids) during the breeding and non-breeding seasons,
\end{abstract}

and also ovariectomized non-breeding season ewes with or without estradiol replacement. In both experiments, Kiss1r expression on $\mathrm{GnRH}$ neurons was unchanged. Finally, we examined the effect of kisspeptin treatment on Kiss1r. Kiss1r expression on GnRH neurons was reduced by kisspeptin infusion. These studies indicate the kisspeptin response is indeed greater during the non-breeding season and this may be due in part to increased Kiss1r expression on GnRH neurons. We also show that kisspeptin may regulate the expression of its own receptor.

Copyright $\odot 2012$ S. Karger AG, Basel

\section{Introduction}

The fundamental link between the environment and reproduction is well established, causing species to reproduce during the most optimal period of the year. Changes in photoperiod provide a representation of circannual time and this change in day length is perceived by the pineal gland and translated into the physiological signal of melatonin secretion. Reproduction, on the other hand, is driven by the gonadotropin-releasing hormone $(\mathrm{GnRH})$ neurons in the brain, which stimulate the pituitary gonadotropes to synthesize and secrete pulses of luteinizing hormone $(\mathrm{LH})$ and produce follicle-stimulating hor-

\section{KARGER}

Fax +41613061234

E-Mail karger@karger.ch

www.karger.com
(C) 2012 S. Karger AG, Basel

$0028-3835 / 12 / 0963-0212 \$ 38.00 / 0$

Accessible online at:

www.karger.com/nen
Jeremy T. Smith

Department of Physiology, Building 13F, Monash University

Clayton, VIC 3880 (Australia)

Tel. +61 399052137

E-Mail jeremy.smith@monash.edu 
mone. In sheep, reproductive activity is seasonal, with the onset of estrous cycling activated during the transition to short-day photoperiod and inhibited by increasing day length [1]. Although the exact mechanisms underlying this seasonal reproduction are yet to be fully understood, it is clear the melatonin 'rhythm' must be detected in the brain by neurons, which then control reproductive function. Kisspeptin neurons in the hypothalamus are prime candidates.

Kisspeptins are the products of the Kissl gene and are recognized, with their G-protein-coupled receptor GPR54 (Kiss1r) [2-4], as critical elements for gonadotropin secretion and normal reproductive function $[5,6]$. Kisspeptins are robust stimulators of $\mathrm{LH}$ in a number of mammalian species [7-11], whether administered peripherally or centrally. Importantly, the stimulatory effect of kisspeptin on gonadotropin secretion appears to be dependent on GnRH secretion, although this has only been monitored indirectly $[8,10,12]$. During the ovine non-breeding (anestrous) period, expression of Kiss 1 mRNA in the arcuate nucleus (ARC) of the hypothalamus is reduced [13], as is the connectivity of kisspeptin neurons to GnRH neurons [14]. Kisspeptin treatment during the anestrous period causes ovulation in ewes [15], strongly suggesting that kisspeptin is a key factor in the neuroendocrine control of the seasonal onset of estrous cycling and the annual reproductive cycle in sheep.

Our previous data suggest the LH response to kisspeptin is greater during the anestrous period compared to the breeding season [16]. Whether this reflects a change in the GnRH sensitivity to kisspeptin is unknown. In humans and sheep, the LH response to kisspeptin also increases immediately preceding the LH surge $[16,17]$. Our recent data suggest that the increase in kisspeptin/LH response in the late follicular phase of the estrous cycle is not due to an increase in kisspeptin stimulation of $\mathrm{GnRH}$ secretion and may be driven by increased sensitivity for GnRH stimulation of LH release from the pituitary [16, 18]. In order to categorically state whether the GnRH secretory response to exogenously administered kisspeptin increases during the anestrous period, we determined if the GnRH response to kisspeptin changes with reproductive state in the ewe in vivo. Using hypophysial portal sampling, we measured GnRH secretion in response to kisspeptin administration to ovary-intact ewes during the anestrous period and during the luteal phase of the breeding season estrous cycle. The secretion of GnRH in response to kisspeptin was increased, so we subsequently determined whether this was due to altered expression of Kiss1r on GnRH neurons.

Seasonal Regulation of the Kisspeptin Response and Kiss1r

\section{Materials and Methods}

\section{Animals and Peptides}

Corriedale ewes of similar age (5-6 years) and weight were maintained at the Monash University Sheep Facility (Werribee, Vic., Australia) under natural conditions of ambient photoperiod and environmental temperature. The experiments were carried out according to the National Health and Medical Research Council/Commonwealth Scientific and Industrial Research Organisation/Australian Animal Commission Code of Practice for the Care and Use of Animals for Experimental Purposes and were approved by the Monash University, School of Biomedical Sciences Animal Ethics Committee. Kisspeptin peptide YNWNSFGLRY-NH2 corresponding to the murine C terminal Kiss1 decapeptide (110-110)-NH2 was obtained from Phoenix Pharmaceuticals Ltd. (Belmont, Calif., USA). This sequence is identical to the C-terminal region of ovine kisspeptin (GenBank accession No. DQ059506).

\section{Experimental Design}

Experiment 1: LH and GnRH Responses to Kisspeptin in Anestrous and Luteal Phase Ewes. Ewes were prepared for hypophysial portal and jugular vein sampling as previously described [19] during the anestrous season and the breeding season. For the latter, estrous cycles were synchronized by an intramuscular injection of the synthetic luteolysin, cloprostenol (Estrumate, $125 \mu \mathrm{g}$; Pitman-Moore, Sydney, N.S.W., Australia) as previously described [16] and were treated during the luteal phase. Blood samples $(5 \mathrm{ml})$ were collected every $10 \mathrm{~min}$ for $4 \mathrm{~h}$. After $2 \mathrm{~h}$, kisspeptin $(50 \mu \mathrm{g}$, diluted in $4 \mathrm{ml}$ physiological saline), or vehicle ( $\mathrm{n}=5-6$ per group), was administered via the jugular cannula. The dose was based on our previous data $[15,16,18]$. Portal blood samples were collected into tubes containing $100 \mu \mathrm{l}$ of $5 \mathrm{~mm}$ bacitracin (Sigma, St. Louis, Mo., USA) and held on ice with corresponding jugular samples; additional samples of jugular blood were collected into bacitracin and served as peripheral controls for the GnRH assay. Plasma was harvested within $10 \mathrm{~min}$ of collection and stored at $-20^{\circ} \mathrm{C}$ for radioimmunoassay. At the completion of portal sampling, sheep were euthanized and ovaries inspected to confirm reproductive phase (the presence of corpora lutea in luteal phase animals).

Experiment 2: Kiss1r mRNA Expression on GnRH Neurons in Anestrous and Luteal Phase Ewes. Ewes were euthanized by an intravenous overdose of sodium pentobarbital (Lethabarb; Virbarc, Peakhurst, N.S.W., Australia) in either the anestrous season or the luteal phase of the estrous cycle ( $n=4-5$ per group). Heads were perfused and the hypothalamus dissected as previously described [20]. Coronal sections $(40 \mu \mathrm{m})$ were cut on a cryostat and placed into cryoprotectant (30\% ethylene glycol, $20 \%$ glycerol in sodium phosphate buffer containing $2 \%$ paraformaldehyde) and stored at $-20^{\circ} \mathrm{C}$ until used for in situ hybridization.

Experiment 3: Kiss1r mRNA Expression on GnRH Neurons in Ovariectomized Ewes during the Non-Breeding and Breeding Season. Because Kiss1r expression on GnRH neurons was elevated during the non-breeding season, we sought to isolate the likely stimulus for this change. Ovariectomized (OVX) ewes $(n=4$ per group) were euthanized during the non-breeding and breeding season and brains prepared for in situ hybridization as above.

Experiment 4: Kiss1r mRNA Expression on GnRH Neurons in Non-Breeding Season OVX Ewes with and without Estradiol Treatment. To further investigate the probable stimulus for the change 
in Kiss1r expression on GnRH neurons, we hypothesized that a change in estradiol concentration may stimulate the reduction in Kiss1r expression during the breeding season. OVX ewes $(n=4-5$ per group) were euthanized during the non-breeding season after 2 weeks of estradiol replacement (OVX+E, $3 \mathrm{~cm}$ subcutaneous silastic estradiol capsule as previously described [13]) or vehicle control (empty capsule). Brains were prepared for in situ hybridization as above.

Experiment 5: Kiss1r mRNA Expression on GnRH Neurons in Non-Breeding Season OVX Ewes Treated with Kisspeptin. The ovine non-breeding season is characterized by a reduction in kisspeptin gene (Kiss1 mRNA) and protein expression in the ARC of the hypothalamus $[13,14]$. We hypothesized that this change may facilitate the change in Kiss1r expression because kisspeptin is known to desensitize Kiss1r $[15,21,22]$. OVX ewes ( $\mathrm{n}=4$ per group) were prepared for lateral ventricle infusions and kisspeptin treatment during the non-breeding season as described previously [23]. The ewes received infusions of either kisspeptin $(5 \mu \mathrm{g} / \mathrm{h}$ ) or artificial cerebrospinal fluid (infusion rate $100 \mu \mathrm{l} / \mathrm{h}$ ) for $20 \mathrm{~h}$. Blood samples were collected every $30 \mathrm{~min}$ for $1 \mathrm{~h}$ before and after the infusion to monitor the $\mathrm{LH}$ response to kisspeptin (data reported previously [23]). After the infusion period, animals were euthanized and brains perfused and sectioned as above for analysis by in situ hybridization.

\section{Digoxigenin-Labeled GnRH and Radio-Labeled Kiss1r cRNA} Riboprobes

The cDNA template for a GnRH riboprobe was generated by PCR with primers containing promoters for T7 RNA polymerase in the antisense direction as previously described [20]. The Gnrh1specific template spanned bases 18-169 of the ovine partial cDNA sequence (GenBank accession No. U02517). A digoxigenin (DIG)labeled antisense $\mathrm{GnRH}$ riboprobe was transcribed with a MEGAscript T7 transcription kit (Ambion, Austin, Tex., USA) and DIG labeling mix (Roche, Indianapolis, Ind., USA) according to the manufacturer's protocol.

The cDNA template for a Kiss1r riboprobe was generated by PCR as above [20]. The Kiss1r-specific template spanned bases 635-714 of the ovine cDNA sequence (GenBank accession No. EU272411). The antisense ovine Kiss1r riboprobe was transcribed from cDNA template with T7 polymerase (Promega, Madison, Wisc., USA) and ${ }^{35}$ S-uridine 5-triphosphate (GE Healthcare Life Sciences) using a standard transcription protocol.

\section{Double-Label in situ Hybridization}

Three sections through the preoptic area (POA) were chosen from each ewe for analysis Kiss1r labeling of GnRH cells. Slides were processed and double-label in situ hybridization performed as previously described [20]. Sections were hybridized with both a ${ }^{35}$ S-labeled Kiss1r probe $\left(5 \times 10^{6} \mathrm{cpm} / \mathrm{ml}\right)$ and DIG-labeled $\mathrm{GnRH}$ probe $(1: 400)$ at $54^{\circ} \mathrm{C}$ overnight. GnRH-mRNA-containing cells were visualized with bright-field microscopy and Kiss1r mRNA was assessed under dark-field illumination. Grain-counting software (ImagePro plus; Media Cybernetics) was used to count the silver grains (Kiss1r mRNA) over each GnRH cell. Signal to background ratios were calculated and cells were considered double labeled with a ratio of 3 or greater. For each ewe, the percentage of GnRH cells with Kiss1r mRNA was averaged for each animal and group means ( \pm SEM) were calculated.

\section{Hormone Radioimmunoassay}

Plasma LH concentrations were measured in duplicate, using the method of Lee et al. [24]. Assay sensitivity was $0.2 \mathrm{ng} / \mathrm{ml}$ and the intra-assay coefficient of variation $(\mathrm{CV})$ was less than $10 \%$ over the range of $0.6-11.3 \mathrm{ng} / \mathrm{ml}$. The inter-assay CV was $9 \%$. GnRH was measured by the method of Jonas et al. [25]. Portal plasma $(1 \mathrm{ml})$ was extracted with acidified methanol, evaporated dry, and then reconstituted in $1 \mathrm{ml}$ assay buffer (recovery of $\mathrm{GnRH}$ was determined using the addition of cold hormone to plasma). All samples were assayed in duplicate. Assay sensitivity was $0.4 \mathrm{pg} / \mathrm{ml}$ and the intra-assay $\mathrm{CV}$ was less than $10 \%$ between 1.6 and $71.2 \mathrm{pg} /$ tube. The inter-assay CV was $4 \%$.

\section{Data Analysis}

In experiment 1 , area under the curve (AUC) for LH was determined using Sigma Plot 9.0 and was derived from baselinecorrected response curves for $2 \mathrm{~h}$ post-treatment $(\mathrm{LH})$ or $1 \mathrm{~h}$ posttreatment $(\mathrm{GnRH})$ as previously described $[16,18]$. All grouped data are presented as the mean \pm SEM. LH/GnRH kisspeptin response curves were assessed by two-way repeated measures ANOVA. Kisspeptin response AUC was assessed by two-way ANOVA. Kiss1r mRNA data was assessed by one-way ANOVA using Tukey's multiple comparison post-hoc test. Differences were considered significant when $\mathrm{p}<0.05$.

\section{Results}

\section{LH and GnRH Responses to Kisspeptin in Anestrous} and Luteal Phase Ewes

In all animals, kisspeptin treatment increased the concentration of $\mathrm{GnRH}$ (in portal plasma) and LH (in jugular venous plasma) compared to vehicle treatment (fig. 1). The $\mathrm{LH}$ response curve to kisspeptin treatment was greater during the anestrous period compared to the luteal phase $(\mathrm{p}<0.05)$. AUC analysis showed the LH response to kisspeptin was 5.8 -fold greater in anestrous ewes than luteal phase ewes ( $\mathrm{p}<0.01$; fig. 1e). The GnRH response to kisspeptin was also greater during the anestrous period compared to the luteal phase $(\mathrm{p}<0.05)$. AUC data showed the response to kisspeptin treatment was 2.2 -fold greater in anestrous ewes compared to luteal phase ewes ( $p<0.05$; fig. 1f).

\section{Kiss1r Expression on GnRH Neurons in Anestrous and Luteal Phase Ewes}

We hypothesized that the change in $\mathrm{GnRH} / \mathrm{LH}$ response to kisspeptin reflects a change in Kiss1r mRNA expression on GnRH neurons. GnRH-positive cell bodies were located in their typical distribution within the forebrain-POA. GnRH neurons showed clusters of silver grains reflecting Kiss1r mRNA (fig. 2a-d). Quantitative analysis showed $90 \pm 4 \%$ of $\mathrm{GnRH}$ mRNA-expressing neurons counted also expressed Kiss1r mRNA in anes- 
Fig. 1. Effect of kisspeptin on LH (a, $\mathbf{b})$ and $\mathrm{GnRH}(\mathbf{c}, \mathbf{d})$ secretion in ovary-intact ewes during the non-breeding (anestrous) and breeding (luteal phase) season. Square symbols indicate kisspeptin treatment (50 $\mu \mathrm{g}$ i.v., delivered at $60 \mathrm{~min}$ ) and circle symbols indicate vehicle control. AUC was calculated from response curves (60-180 $\mathrm{min}$ for $\mathrm{LH}$ and 60-120 min for $\mathrm{GnRH})(\mathbf{e , f})$. Repeated measures ANOVA revealed a significant effect of kisspeptin treatment for both LH and $\mathrm{GnRH}(\mathrm{p}<0.05)$. Analysis also revealed a significant effect of breeding season (anestrous vs. luteal). The LH and GnRH response to kisspeptin treatment was greater during the non-breeding season compared to the breeding season, ${ }^{*} \mathrm{p}<0.05,{ }^{* *} \mathrm{p}<0.01$. Values are the mean $\pm \operatorname{SEM}$ ( $\mathrm{n}=5-6$ per group).
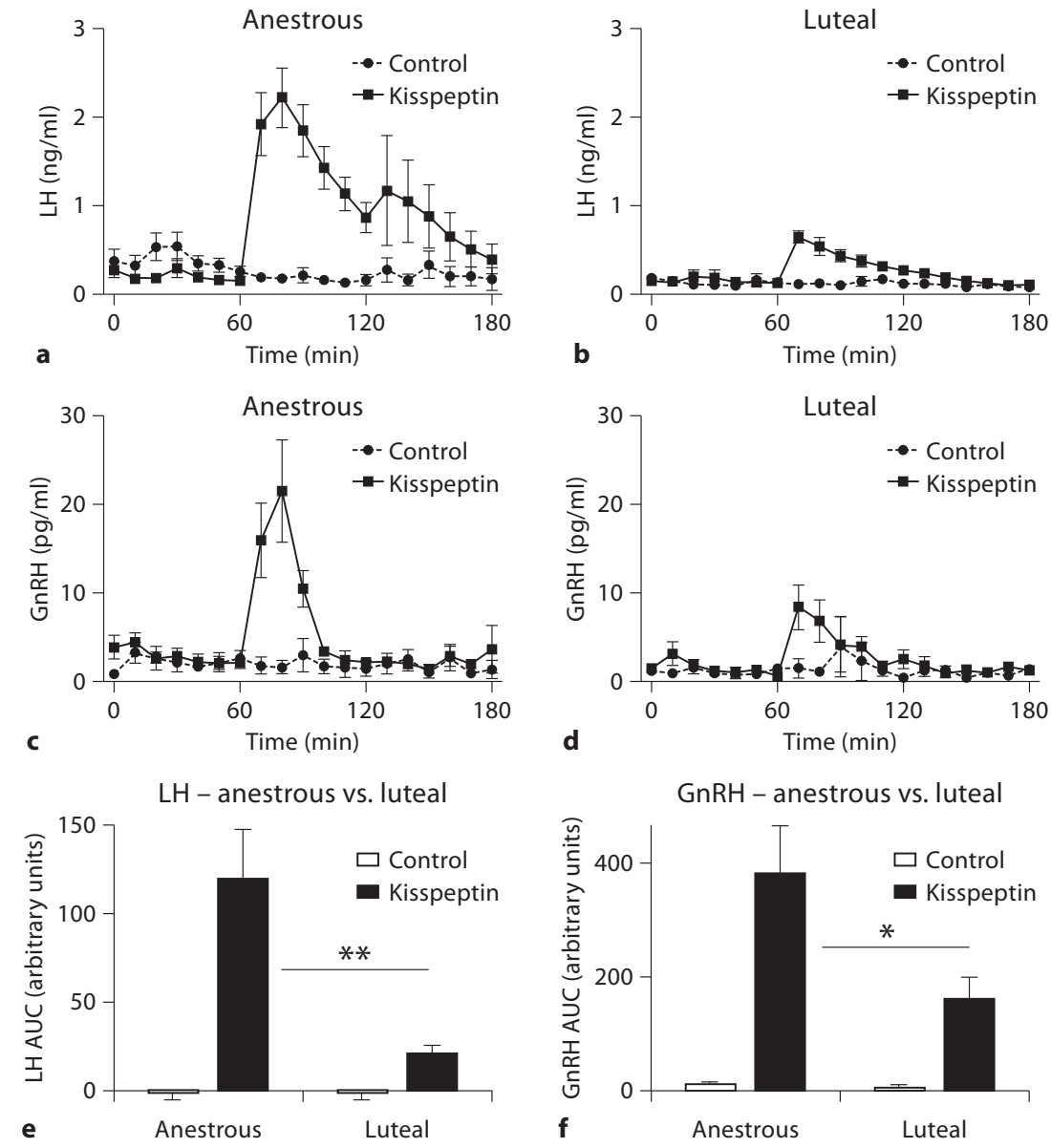

GnRH - anestrous vs. luteal

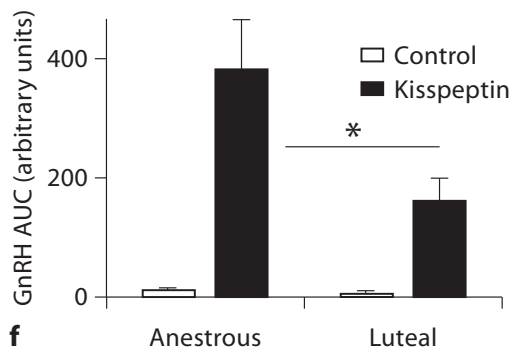

trous ewes (fig. 2e). The percentage of GnRH neurons expressing Kiss1r was significantly $(\mathrm{p}<0.05)$ lower in luteal phase ewes $(78 \pm 2 \%)$. Similarly, the relative expression of Kiss1r mRNA (number of silver grains) on GnRH neurons was $37 \%$ lower in luteal phase ewes compared to anestrous ewes ( $p<0.05$; fig. $2 \mathrm{f}$ ). The number of $\mathrm{GnRH}$ mRNA-expressing neurons was similar between groups (anestrous $51 \pm 14$ cells, luteal $30 \pm 5$ cells).

\section{Kiss1r Expression on GnRH Neurons in OVX Ewes during the Non-Breeding and Breeding Season}

To further examine the mechanism underlying the change in Kiss1r on GnRH neurons between seasons, we quantified Kiss1r/GnRH expression in OVX ewes (to eliminate ovarian steroids) during the breeding and nonbreeding seasons. The percentage of $\mathrm{GnRH}$ neurons expressing Kiss1r and the relative expression of Kiss1r
mRNA (silver grains per cell) on GnRH neurons was similar in these two groups (fig. 3a, b), as were the numbers of GnRH mRNA-expressing neurons (non-breeding season $64 \pm 20$ cells, breeding season $50 \pm 9$ cells).

\section{Kiss1r Expression on GnRH Neurons in OVX Ewes}

Treated with Estradiol in the Non-Breeding Season

Because we found similar levels of Kiss1r gene expression in OVX ewes, we ascertained whether the seasonal change in responsiveness is due to differing levels of sex steroids. The percentage of $\mathrm{GnRH}$ neurons expressing Kiss1r and the relative expression of Kiss1r mRNA (number of silver grains) on GnRH neurons was similar in OVX ewes with and without estradiol treatment during the non-breeding season (fig. $3 \mathrm{c}-\mathrm{d}$ ). The number of GnRH mRNA-expressing neurons was also similar in the two groups (OVX $16 \pm 4$ cells, OVX+E $24 \pm 10$ cells). 


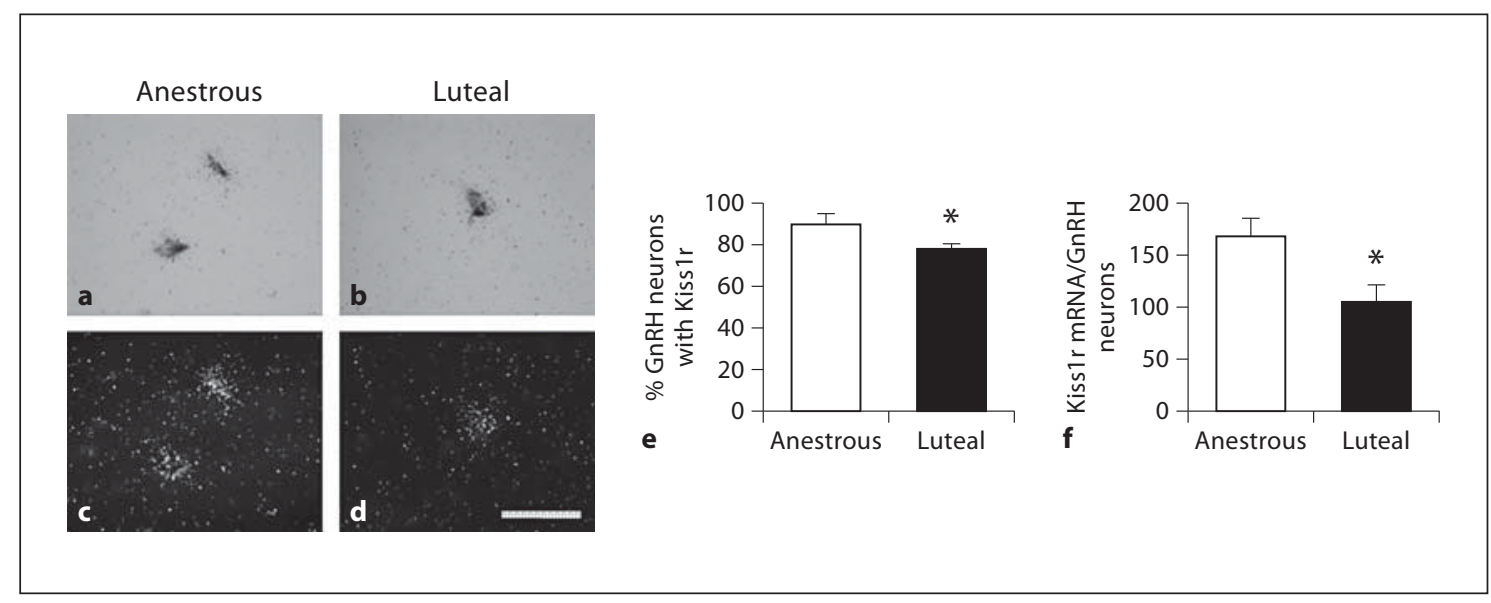

Fig. 2. Expression of Kiss1r mRNA in GnRH neurons in the nonbreeding (anestrous) and breeding (luteal phase) season. a, b Representative bright-field photomicrographs show GnRH mRNAexpressing cells visualized with nitroblue tetrazolium substrate. c, d Corresponding dark-field photomicrographs show co-expression of Kiss1r mRNA (clusters of silver grains; note: silver grains can also be seen in bright-field illumination). Scale bar: $50 \mu \mathrm{m}$. e, $\mathbf{f}$ Quantitative analysis of Kiss1r mRNA in GnRH neurons demonstrated the percentage of double-labeled cells (e) was greater in anestrous phase ewes compared to luteal phase ewes. Similarly, the relative expression of Kiss1r mRNA in GnRH neurons (f, reflected by the number of silver grains per GnRH neuron) was greater in anestrous phase ewes ( $n=4-5$ per group). Data are the mean \pm SEM, ${ }^{*} \mathrm{p}<0.05$.

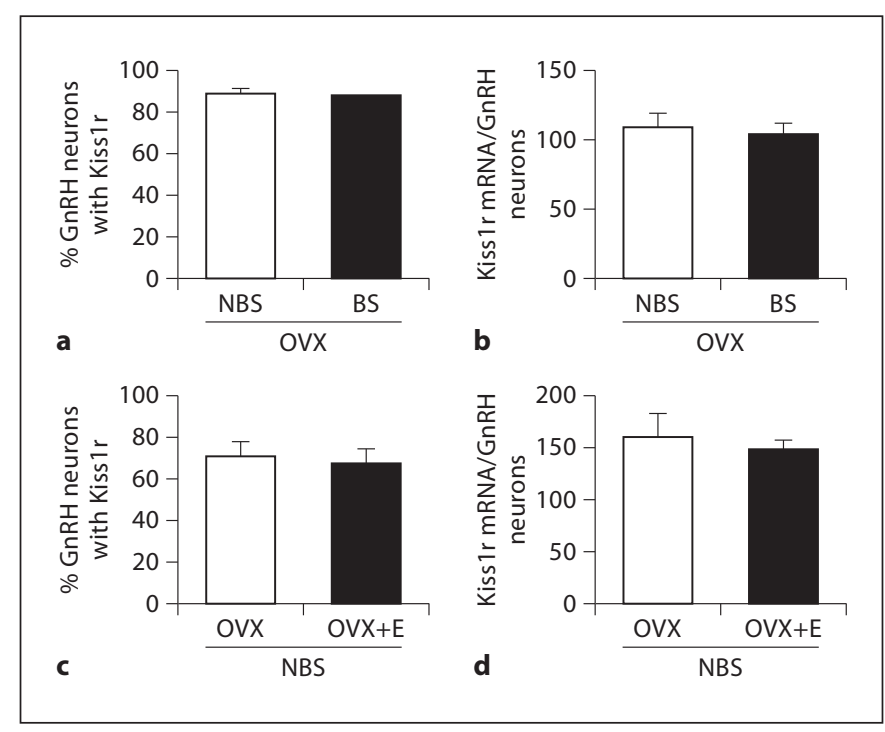

Fig. 3. Quantitative analysis of Kisslr mRNA in GnRH neurons. a, $\mathbf{b}$ The percentage co-expression and relative expression of Kiss1r on GnRH neurons was similar between the non-breeding (NBS) and breeding season (BS) in OVX ewes. c, d Similarly coexpression and relative expression was also unchanged during the non-breeding season in OVX and OVX+E ewes. Values are the mean $\pm \operatorname{SEM}(\mathrm{n}=4$ per group).

\section{Kiss1r mRNA Expression on GnRH Neurons in OVX Ewes Treated with Kisspeptin during the \\ Non-Breeding Season}

We hypothesized that the seasonal change in Kiss1r mRNA expression on GnRH neurons is related to the lower level of Kiss 1 expression and kisspeptin production in the non-breeding season [13]. Quantitative analysis showed the percentage of GnRH neurons expressing Kiss1r was significantly $(\mathrm{p}<0.05)$ lower in kisspeptintreated ewes $(36 \pm 7 \%)$ compared to vehicle-treated controls (64 $\pm 5 \%$; fig. $4 \mathrm{a}-\mathrm{e}$ ). Similarly, the relative expression of Kiss1r mRNA (silver grains per cell) on GnRH neurons was 32\% lower in kisspeptin-treated ewes compared to control ewes ( $p<0.05$; fig. $4 \mathrm{f})$. The number of GnRH mRNA-expressing neurons was similar between groups (kisspeptin treated $40 \pm 14$ cells, control $23 \pm 6$ cells).

\section{Discussion}

Kisspeptin signaling is fundamental to reproductive function $[5,6]$ and the stimulatory effect of kisspeptin on $\mathrm{GnRH}$ /gonadotropin secretion is unequivocal. We show herein that the LH response to kisspeptin is greater during the non-breeding season in the ewe and that this change reflects an increase in kisspeptin stimulation of 


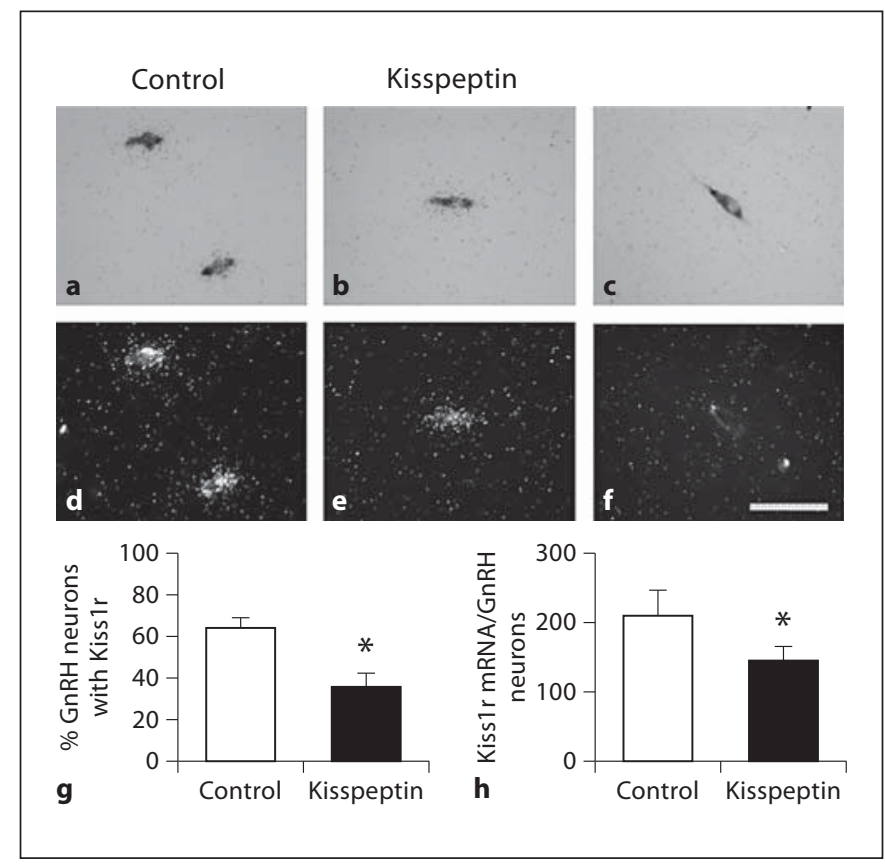

Fig. 4. Expression of Kiss1r mRNA in GnRH neurons after kisspeptin treatment during the non-breeding (anestrous) season. a-c Representative bright-field photomicrographs show $\mathrm{GnRH}$ mRNA-expressing cells. d-f Corresponding dark-field photomicrographs show co-expression of Kiss1r mRNA (clusters of silver grains) in $\mathbf{d}$ and $\mathbf{e}$, no co-expression is seen in $\mathbf{f}$. Scale bar: $50 \mu \mathrm{m}$. $\mathbf{g}, \mathbf{h}$ Quantitative analysis of Kiss1r mRNA in GnRH neurons showed the percentage of double-labeled cells (g) was reduced with kisspeptin treatment compared to controls (vehicle-treated). Similarly, the relative expression of Kiss1r mRNA in GnRH neurons (h), reflected by the number of silver grains per GnRH neuron, was reduced after kisspeptin treatment ( $n=4$ per group). Data are the mean \pm SEM, ${ }^{*} \mathrm{p}<0.05$.

GnRH secretion into the hypophysial portal system. This change in the response to kisspeptin can be explained, at least in part, by an increase in Kisslr expression by GnRH neurons during the non-breeding season. The cause for this change in receptor expression does not appear to be the direct result of changes in seasonal photoperiod independent of circulating levels of estradiol or the direct effect of estradiol alone. Interestingly, prolonged kisspeptin treatment appeared to downregulate the expression of Kiss1r, which may explain, in part, a decline in Kiss1r expression on GnRH neurons during the breeding season when Kiss1 mRNA expression is high.

This is the first report in any species of a direct change in the secretion of $\mathrm{GnRH}$ in response to kisspeptin. In particular, using a seasonal model, we show that the response is increased in the anestrous state. The functional significance of this increase in sensitivity is not immediately clear. One possibility is that increased Kiss1r and sensitivity of GnRH cells to kisspeptin during the nonbreeding season allows for a greater 'sense' for the increasing levels of Kiss1 expression in the ARC of the hypothalamus, which occur at the onset of the breeding season $[13,14]$, enabling the renaissance of pulsatile $\mathrm{GnRH}$ secretion. Kiss $1 \mathrm{mRNA}$ and expression in the ARC is elevated at the onset of the ovine breeding season [26], even in the absence of gonadal sex steroid feedback [13], indicating that kisspeptin is fundamental to the seasonal change in reproductive function. The number of kisspeptin-immunoreactive cells is greater in the ARC, and the number of kisspeptin terminal appositions onto GnRH neurons is greater during the breeding season [14]. Importantly, the inhibitory feedback effects of estrogen on kisspeptin expression in the ARC are greater during the non-breeding season [14]. Thus, the seasonal change in sensitivity to estrogen-negative feedback, which is a major mechanism for seasonal breeding, is most likely to be effected, at least in part, by changing responsiveness of kisspeptin neurons to estradiol.

Another explanation is simpler. There is reduced $\mathrm{GnRH} / \mathrm{LH}$ pulse frequency in the anestrous season and this may allow a buildup of the releasable pool of $\mathrm{GnRH}$, between pulses, in the anestrous season. Certainly a reduction in GnRH/LH pulse frequency leads to an increase in LH pulse amplitude at the level of the pituitary gonadotrope [27], and the releasable pool of LH is directly related to the amplitude of $\mathrm{LH}$ pulses affected by a $\mathrm{GnRH}$ challenge. A similar mechanism may pertain in $\mathrm{GnRH}$ cells. Our previous data show no difference in the size of the GnRH and LH response to repeated administration of kisspeptin in ewes during the non-breeding season [15]. Thus, it appears the anestrous kisspeptin response was not diminished with a possible reduction in the releasable pool of GnRH brought about from multiple stimulations. Nevertheless, there is no difference in the amount of $\mathrm{GnRH}$ in the hypothalamus or median eminence in either the breeding or the non-breeding seasons [28], but a measure of how much peptide is in the readily releasable pool or how long it would take to replenish $\mathrm{GnRH}$ in the releasable pool has never been quantified. Perhaps this is a logical explanation for the present results.

Our data are similar to those in the Siberian hamster (also a seasonal breeder) where the LH response to kisspeptin appears greater in females held at short-day (nonbreeding season) photoperiod [29]. On the other hand, conflicting data show no effect of repeated kisspeptin ad- 
ministration in this species held at short-day photoperiod [30]. Changes in the responsiveness of LH to kisspeptin have also been reported in a number of other experimental models. Acute inflammation reduces LH responsiveness to kisspeptin in rats [31], while short-term fasting appears to augment the LH response to kisspeptin [32]. Conversely, short-term fasting in the non-human primate attenuates the response of the HPG axis to kisspeptin [33]. It is thought that the seasonal shift from the anestrous state to the active state is similar to that pertaining to the onset of puberty [34]. Thus, it is interesting to note the response to high doses of kisspeptin is greater in pre-pubertal than post-pubertal mice [35], although these pre-pubertal animals appeared unresponsive to lower doses of kisspeptin. Whether these above changes are specific to the effect of kisspeptin on GnRH (as we have shown) or just a change in the sensitivity of LH to GnRH is not known.

The expression of Kiss1r on GnRH neurons correlated with the higher response of GnRH cells to kisspeptin during the non-breeding season. This may be the primary basis for the change in GnRH response to kisspeptin. To further elucidate the mechanism underlying the change in Kiss1r, we examined the effects of breeding season on Kiss1r expression on GnRH neurons in OVX ewes (to control for levels of sex steroids). We found no difference in the expression of Kiss1r, indicating that photoperiod is not the sole regulator of the receptors expression on GnRH neurons. We further looked at the effect of estradiol on Kisslr expression on GnRH neurons during the non-breeding season, because sex steroid concentrations increase during the breeding season and estrogen signaling appears to have a role in Kisslr regulation [36] and kisspeptin sensitivity [37], with divergent roles for estrogen receptor- $\alpha$ and - $\beta$ in modulating this response. Again we saw no difference in Kiss1r expression on GnRH neurons between OVX and OVX+E animals. Thus, we conclude that the decline in Kiss1r expression on GnRH neurons during the breeding season is not due solely to an increase in estradiol at this time. Alternatively, there may be a seasonal change in the Kiss1r response to estradiol, such that basal levels of estradiol only inhibit Kiss1r during the breeding season and not the non-breeding season. Such an effect would be intriguing and opposite to the seasonal shift in estradiol-negative feedback sensitivity (greater during the non-breeding season). Whether changes in other sex steroids such as progesterone, which inhibits Kiss1 expression [13], or combinations of sex steroids regulate Kiss1r expression on $\mathrm{GnRH}$ neurons is yet to be determined.
We hypothesized that the rise in Kiss1 mRNA and kisspeptin expression in the ovine hypothalamus during the breeding season $[13,26]$ is the stimulus for the decline in Kiss1r expression seen at this time. Kisspeptin desensitization of Kiss1r signaling has been demonstrated in the non-human primate [21] and the rat [22] and we have provided data from sheep that is consistent with this phenomenon [15]. Our data show a significant decrease in Kiss1r expression on GnRH neurons following continuous $(20 \mathrm{~h})$ central treatment of kisspeptin. It is likely this infusion of kisspeptin resulted in Kiss1r desensitization because the LH concentration was not significantly different before and after the infusion period [23]. Thus, it is possible the increase in Kiss1 expression and kisspeptin protein output observed during the breeding season cause a decline in Kiss1r expression on GnRH neurons. The molecular mechanisms underlying Kiss1r desensitization are yet to be fully explored, but may include Gprotein-coupled receptor serine/threonine kinase activity [38]. Our data suggest kisspeptin may regulate the transcription of its receptor, decreasing the generation of new receptors.

If kisspeptin neuropeptide output was a stimulus for the change in Kisslr expression on GnRH neurons, the question arises why no change was seen in OVX animals, when Kiss1 expression is upregulated in the ARC, compared to OVX+E animals $[13,14]$. We feel this may relate to the relative expression of both major Kiss1 neuronal populations. In OVX animals, Kiss1 expression increases in the ARC, but decreases in the POA, compared to OVX+E [14]. We predict in ovary-intact ewes, Kiss1 expression in both the ARC and POA would increase with the transition to breeding season and such a change may mediate the decline in Kiss1r.

We recently showed the $\mathrm{LH}$ response to kisspeptin was greater during the late follicular phase of the ovine estrous cycle $[16,18]$. Similarly, in humans and rats, the LH response to kisspeptin treatment appears to be highest during the preovulatory phase of the menstrual/estrous cycle $[17,39]$. However, the GnRH secretory response (measured directly in portal blood) to kisspeptin was similar in the luteal and follicular phases of the estrous cycle of the ewe [18]. Consistent with this, Kiss1r mRNA expression on $\mathrm{GnRH}$ neurons was similar in luteal and late follicular phase animals [18]. It is not surprising then that GnRH has its greatest effect (stimulating LH secretion) during the late preovulatory phase of cycle in humans [40] and sheep [41] and this is substantially due to increased pituitary sensitivity to $\mathrm{GnRH}$ just prior to the onset of the LH surge. Thus, just prior to ovulation the 
increased LH response to kisspeptin is mediated via the pituitary gonadotrope response to $\mathrm{GnRH}$ and not via a direct effect on GnRH secretion, as is seen during the non-breeding season.

It remains possible that the increase in $\mathrm{LH}$ release during the non-breeding season may be attributable to additional output directly from the pituitary gland. We feel this is unlikely because the stimulatory effect of kisspeptin on gonadotropin secretion appears to be dependent on GnRH. Evidence for this includes: (1) the stimulatory effect of kisspeptin is blocked in the presence of GnRH antagonists [8, 9, 11, 42] or GnRH antiserum [43]; (2) discrete intranuclear injection of kisspeptin into the rat POA, where most GnRH neurons reside, stimulates LH secretion [44]; (3) kisspeptin induces Fos (the immediate early gene product) in GnRH neurons [9, 42]; (4) kisspeptin directly increases $\mathrm{GnRH}$ neuron excitability $[35,45]$; (5) kisspeptin-immunoreactive fibers make close appositions to GnRH neurons [14, 46, 47], which express Kiss1r [20, 35, 42], and (5) in rat hypothalamic explants, kisspeptin stimulates $\mathrm{GnRH}$ release [48] and also does so in vivo in sheep $[10,18]$. Despite this, in vitro evidence suggests kisspeptin may play a role in gonadotropin secretion from the pituitary [49]; however, kisspeptin has no direct effect on pituitary LH release in vivo in an ovine hypothalamo-pituitary disconnection model [12].

In our experiments detailing Kiss1r co-expression on GnRH neurons, we focused on the GnRH neurons within the POA. This POA population represents the majority of $\mathrm{GnRH}$ neurons within the ovine brain and project to the median eminence $[50,51]$ where they are very likely to be stimulated by kisspeptin neurons to mediate the pulsatile secretion of $\mathrm{GnRH}[18,48]$. Alternatively, it is suggested that GnRH neurons located in the mediobasal hypothalamus are also the conduit for pulsatile $\mathrm{GnRH} /$ LH secretion. This evidence comes from studies where increased LH pulsatile secretion, induced by opioid antagonist treatment, induced fos expression in mediobasal hypothalamic GnRH neurons but not GnRH neurons in the POA [52]. Thus, it is likely (but not yet determined) the small population of GnRH neurons within the mediobasal hypothalamus co-express Kiss1r and breeding season status may also regulate its expression. In our studies we observed a trend for decreased GnRH/Kiss1r co-expression in non-breeding season animals in experiments 4 and 5 . We have no definitive explanation for this, although animals in experiment 5 were examined during the early non-breeding season (August), which may indicate a shifting away from the breeding season state. Importantly, these data were obtained from separate in situ hybridizations (and developed separately) and hence valid analysis between experiments cannot be undertaken.

In conclusion, our data show the kisspeptin GnRH/ $\mathrm{LH}$ response is greater during the non-breeding season, which may be due, in part, to increased Kisslr expression by GnRH neurons. This increase in Kiss1r does not appear to be the result of independent effects of seasonal status or estradiol levels, although the combination of both and/or progesterone regulation cannot be ruled out. Finally, we show Kiss1r expression on GnRH neurons is reduced with prolonged kisspeptin treatment. We conclude that, during the non-breeding season, GnRH neurons are primed to receive and respond to kisspeptin for the re-initiation of the breeding season. Alternatively, the relationship may simply relate to the inverse relationship between GnRH pulse frequency and amplitude. One stimulus for the increase in sensitivity may be the decline in kisspeptin expression during the non-breeding season.

\section{Acknowledgements}

We thank Bruce Doughton, Lynda Morrish, Elaine Chase and Sofie Saleh for their technical assistance. Grant Support: Supported by the National Health and Medical Research Council of Australia (NHMRC) project grant 606538. J.T.S. is supported by an Australian Research Council Future Fellowship FT0990986.

\section{Disclosure Statement}

The authors have no conflicts of interest to disclose.

$\begin{aligned} \text { References } & \text { Karsch FJ, Robinson JE, Woodfill CJ, Brown } \\ & \text { MB: Circannual cycles of luteinizing hor- } \\ & \text { mone and prolactin secretion in ewes during } \\ & \text { prolonged exposure to a fixed photoperiod: } \\ & \text { evidence for an endogenous reproductive } \\ & \text { rhythm. Biol Reprod 1989;41:1034-1046. } \\ 2 & \text { Kotani M, Detheux M, Vandenbogaerde A, } \\ & \text { Communi D, Vanderwinden JM, Le Poul E, } \\ & \text { Brezillon S, Tyldesley R, Suarez-Huerta N, } \\ & \text { Vandeput F, Blanpain C, Schiffmann SN, } \\ & \text { Vassart G, Parmentier M: The metastasis } \\ & \text { suppressor gene KiSS-1 encodes kisspeptins, } \\ & \text { the natural ligands of the orphan G-protein- } \\ & \text { coupled receptor GPR54. J Biol Chem 2001; } \\ & 276: 34631-3466 .\end{aligned}$


-3 Muir AI, Chamberlain L, Elshourbagy NA, Michalovich D, Moore DJ, Calamari A, Szekeres PG, Sarau HM, Chambers JK, Murdock P, Steplewski K, Shabon U, Miller JE, Middleton SE, Darker JG, Larminie CG, Wilson S, Bergsma DJ, Emson P, Faull R, Philpott KL, Harrison DC: AXOR12, a novel human G-protein-coupled receptor, activated by the peptide KiSS-1. J Biol Chem 2001; 276:28969-28975.

4 Ohtaki T, Shintani Y, Honda S, Matsumoto H, Hori A, Kanehashi K, Terao Y, Kumano S, Takatsu Y, Masuda Y, Ishibashi Y, Watanabe T, Asada M, Yamada T, Suenaga M, Kitada C, Usuki S, Kurokawa T, Onda H, Nishimura O, Fujino M: Metastasis suppressor gene KiSS-1 encodes peptide ligand of a G-protein-coupled receptor. Nature 2001;411:613-617.

5 De Roux N, Genin E, Carel JC, Matsuda F, Chaussain JL, Milgrom E: Hypogonadotropic hypogonadism due to loss of function of the KiSS1-derived peptide receptor GPR54. Proc Natl Acad Sci USA 2003;100: 10972-10976.

-6 Seminara SB, Messager S, Chatzidaki EE, Thresher RR, Acierno JS Jr, Shagoury JK, BoAbbas Y, Kuohung W, Schwinof KM, Hendrick AG, Zahn D, Dixon J, Kaiser UB, Slaugenhaupt SA, Gusella JF, O'Rahilly S, Carlton MB, Crowley WF Jr, Aparicio SA, Colledge WH: The GPR54 gene as a regulator of puberty. N Engl J Med 2003;349:16141627.

-7 Dhillo WS, Chaudhri OB, Patterson M, Thompson EL, Murphy KG, Badman MK, McGowan BM, Amber V, Patel S, Ghatei MA, Bloom SR: Kisspeptin-54 stimulates the hypothalamic-pituitary gonadal axis in human males. J Clin Endocrinol Metab 2005; 90:6609-6615.

8 Gottsch ML, Cunningham MJ, Smith JT, Popa SM, Acohido BV, Crowley WF, Seminara S, Clifton DK, Steiner RA: A role for kisspeptins in the regulation of gonadotropin secretion in the mouse. Endocrinology 2004;145:4073-4077.

-9 Matsui H, Takatsu Y, Kumano S, Matsumoto $\mathrm{H}$, Ohtaki T: Peripheral administration of metastin induces marked gonadotropin release and ovulation in the rat. Biochem Biophys Res Commun 2004;320:383-388.

10 Messager S, Chatzidaki EE, Ma D, Hendrick AG, Zahn D, Dixon J, Thresher RR, Malinge I, Lomet D, Carlton MB, Colledge $\mathrm{WH}$, Caraty A, Aparicio SA: Kisspeptin directly stimulates gonadotropin-releasing hormone release via G-protein-coupled receptor 54 . Proc Natl Acad Sci USA 2005; 102:1761-1766.

- 11 Shahab M, Mastronardi C, Seminara SB, Crowley WF, Ojeda SR, Plant TM: Increased hypothalamic GPR54 signaling: a potential mechanism for initiation of puberty in primates. Proc Natl Acad Sci USA 2005;102: 2129-2134.
2 Smith JT, Rao A, Pereira A, Caraty A, Millar $\mathrm{RP}$, Clarke IJ: Kisspeptin is present in ovine hypophysial portal blood but does not increase during the preovulatory luteinizing hormone surge: evidence that gonadotropes are not direct targets of kisspeptin in vivo. Endocrinology 2008;149:1951-1959.

13 Smith JT, Clay CM, Caraty A, Clarke IJ: KiSS-1 messenger ribonucleic acid expression in the hypothalamus of the ewe is regulated by sex steroids and season. Endocrinology 2007;148:1150-1157.

14 Smith JT, Coolen LM, Kriegsfeld LJ, Sari IP, Jaafarzadehshirazi MR, Maltby M, Bateman K, Goodman RL, Tilbrook AJ, Ubuka T, Bentley GE, Clarke IJ, Lehman MN: Variation in kisspeptin and RF-amide-related peptide expression and terminal connections to gonadotropin-releasing hormone neurons in the brain: a novel medium for seasonal breeding in the sheep. Endocrinol ogy 2008; 149:5770-5782.

15 Caraty A, Smith JT, Lomet D, Ben Said S, Morrissey A, Cognie J, Doughton B, Baril G, Briant C, Clarke IJ: Kisspeptin synchronizes preovulatory surges in cyclical ewes and causes ovulation in seasonally acyclic ewes. Endocrinology 2007;148:5258-5267.

16 Smith JT, Saleh SN, Clarke IJ: Seasonal and cyclical change in the luteinizing hormone response to kisspeptin in the ewe. Neuroendocrinology 2009;90:283-291.

17 Dhillo WS, Chaudhri OB, Thompson EL, Murphy KG, Patterson M, Ramachandran R, Nijher GK, Amber V, Kokkinos A, Donaldson M, Ghatei MA, Bloom SR: Kisspeptin-54 stimulates gonadotropin release most potently during the preovulatory phase of the menstrual cycle in women. J Clin Endocrinol Metab 2007;92:3958-3966.

18 Smith JT, Li Q, Yap KS, Shahab M, Roseweir AK, Millar RP, Clarke IJ: Kisspeptin is essential for the full preovulatory LH surge and stimulates $\mathrm{GnRH}$ release from the isolated ovine median eminence. Endocrinology 2011;152:1001-1012.

19 Clarke IJ: Two decades of measuring GnRH secretion. Reprod Suppl 2002;59:1-13.

20 Smith JT, Li Q, Pereira A, Clarke IJ: Kisspeptin neurons in the ovine arcuate nucleus and preoptic area are involved in the preovulatory luteinizing hormone surge. Endocrinology 2009;150:5530-6638.

21 Seminara SB, Dipietro MJ, Ramaswamy S, Crowley WF Jr, Plant TM: Continuous human metastin 45-54 infusion desensitizes G-protein-coupled receptor 54-induced gonadotropin-releasing hormone release monitored indirectly in the juvenile male Rhesus monkey (Macaca mulatta): a finding with therapeutic implications. Endocrinology 2006;147:2122-2126.
22 Roa J, Vigo E, Garcia-Galiano D, Castellano JM, Navarro VM, Pineda R, Dieguez C, Aguilar E, Pinilla L, Tena-Sempere M: Desensitization of gonadotropin responses to kisspeptin in the female rat: analyses of $\mathrm{LH}$ and FSH secretion at different developmental and metabolic states. Am J Physiol Endocrinol Metab 2008;294:E1088-E1096.

23 Backholer K, Smith JT, Rao A, Pereira A, Iqbal J, Ogawa S, Li Q, Clarke IJ: Kisspeptin cells in the ewe brain respond to leptin and communicate with neuropeptide $\mathrm{Y}$ and proopiomelanocortin cells. Endocrinology 2010;151:2233-2243.

24 Lee VW, Cumming IA, de Kretser DM, Findlay JK, Hudson B, Keogh EJ: Regulation of gonadotrophin secretion in rams from birth to sexual maturity. I. Plasma LH, FSH and testosterone levels. J Reprod Fertil 1976;46: $1-6$.

-25 Jonas HA, Burger HG, Cumming IA, Findlay JK, de Kretser DM: Radioimmunoassay for luteinizing hormone-releasing hormone (LHRH): its application to the measurement of LHRH in ovine and human plasma. Endocrinology 1975;96:384-393.

-26 Wagner GC, Johnston JD, Clarke IJ, Lincoln GA, Hazlerigg DG: Redefining the limits of day length responsiveness in a seasonal mammal. Endocrinology 2008;149:32-39.

-27 Clarke IJ, Cummins JT: GnRH pulse frequency determines LH pulse amplitude by altering the amount of releasable LH in the pituitary glands of ewes. J Reprod Fertil 1985;73:425-431.

28 Clarke IJ, Pompolo S: Synthesis and secretion of GnRH. Anim Reprod Sci 2005;88: 29-55.

29 Greives TJ, Long KL, Burns CM, Demas GE: Response to exogenous kisspeptin varies according to sex and reproductive condition in Siberian hamsters (Phodopus sungorus). Gen Comp Endocrinol 2011;170:172-179.

30 Mason AO, Greives TJ, Scotti MA, Levine J, Frommeyer S, Ketterson ED, Demas GE, Kriegsfeld LJ: Suppression of kisspeptin expression and gonadotropic axis sensitivity following exposure to inhibitory day lengths in female Siberian hamsters. Horm Behav 2007;52:492-498.

- 31 Castellano JM, Bentsen AH, Romero M, Pineda R, Ruiz-Pino F, Garcia-Galiano D, Sanchez-Garrido MA, Pinilla L, Mikkelsen JD, Tena-Sempere M: Acute inflammation reduces kisspeptin immunoreactivity at the arcuate nucleus and decreases responsiveness to kisspeptin independently of its anorectic effects. Am J Physiol Endocrinol Metab 2010;299:E54-E61.

32 Castellano JM, Navarro VM, FernandezFernandez R, Nogueiras R, Tovar S, Roa J, Vazquez MJ, Vigo E, Casanueva FF, Aguilar E, Pinilla L, Dieguez C, Tena-Sempere M: Changes in hypothalamic KiSS-1 system and restoration of pubertal activation of the reproductive axis by kisspeptin in undernutrition. Endocrinology 2005;146:3917-3925. 
-33 Wahab F, Aziz F, Irfan S, Zaman WU, Shahab M: Short-term fasting attenuates the response of the HPG axis to kisspeptin challenge in the adult male rhesus monkey ( $\mathrm{Ma}$ caca mulatta). Life Sci 2008;83:633-637.

34 Smith JT, Clarke IJ: Seasonal breeding as a neuroendocrine model for puberty in sheep. Mol Cell Endocrinol 2010;324:102-109.

- 35 Han SK, Gottsch ML, Lee KJ, Popa SM, Smith JT, Jakawich SK, Clifton DK, Steiner RA, Herbison AE: Activation of gonadotropin-releasing hormone neurons by kisspeptin as a neuroendocrine switch for the onset of puberty. J Neurosci 2005;25:1134911356.

- 36 Navarro VM, Castellano JM, FernandezFernandez R, Barreiro ML, Roa J, SanchezCriado JE, Aguilar E, Dieguez C, Pinilla L, Tena-Sempere M: Developmental and hormonally regulated messenger ribonucleic acid expression of KiSS-1 and its putative receptor, GPR54, in rat hypothalamus and potent luteinizing hormone-releasing activity of KiSS-1 peptide. Endocrinology 2004; 145 : 4565-4574.

-37 Roa J, Vigo E, Castellano JM, Gaytan F, Navarro VM, Aguilar E, Dijcks FA, Ederveen AG, Pinilla L, van Noort PI, Tena-Sempere $\mathrm{M}$ : Opposite roles of estrogen receptor (ER)$\alpha$ and ER- $\beta$ in the modulation of luteinizing hormone responses to kisspeptin in the female rat: implications for the generation of the preovulatory surge. Endocrinology 2008; 149:1627-1637.

- 38 Pampillo M, Camuso N, Taylor JE, Szereszewski JM, Ahow MR, Zajac M, Millar RP, Bhattacharya M, Babwah AV: Regulation of GPR54 signaling by GRK2 and $\beta$-arrestin. Mol Endocrinol 2009;23:2060-2074.
39 Roa J, Vigo E, Castellano JM, Navarro VM, Fernandez-Fernandez R, Casanueva FF, Dieguez C, Aguilar E, Pinilla L, Tena-Sempere M: Hypothalamic expression of KiSS-1 system and gonadotropin-releasing effects of kisspeptin in different reproductive states of the female Rat. Endocrinology 2006; 147: 2864-2878.

40 De Kretser DM, Burger HG, Dumpys R: Patterns of serum LH and FSH in response to 4-hour infusions of luteinizing hormone-releasing hormone in normal women during menstrual cycle, on oral contraceptives, and in postmenopausal state. J Clin Endocrinol Metab 1978;46:227-235.

41 Clarke IJ: Evidence that the switch from negative to positive feedback at the level of the pituitary gland is an important timing event for the onset of the preovulatory surge in $\mathrm{LH}$ in the ewe. J Endocrinol 1995; 145:271-282.

42 Irwig MS, Fraley GS, Smith JT, Acohido BV, Popa SM, Cunningham MJ, Gottsch ML, Clifton DK, Steiner RA: Kisspeptin activation of gonadotropin-releasing hormone neurons and regulation of KiSS-1 mRNA in the male rat. Neuroendocrinology 2004;80: 264-272.

43 Arreguin-Arevalo JA, Lents CA, Farmerie TA, Nett TM, Clay CM: KiSS-1 peptide induces release of LH by a direct effect on the hypothalamus of ovariectomized ewes. Anim Reprod Sci 2007;101:265-275.

44 Patterson M, Murphy KG, Thompson EL, Patel S, Ghatei MA, Bloom SR: Administration of kisspeptin-54 into discrete regions of the hypothalamus potently increases plasma luteinising hormone and testosterone in male adult rats. J Neuroendocrinol 2006;18: 349-354.

45 Pielecka-Fortuna J, Chu Z, Moenter SM: Kisspeptin acts directly and indirectly to increase gonadotropin-releasing hormone neuron activity and its effects are modulated by estradiol. Endocrinology 2008;149:19791986.
6 Clarkson J, Herbison AE: Postnatal development of kisspeptin neurons in mouse hypothalamus; sexual dimorphism and projections to gonadotropin-releasing hormone neurons. Endocrinology 2006; 147:5817-5825.

47 Kinoshita M, Tsukamura H, Adachi S, Matsui $\mathrm{H}$, Uenoyama $\mathrm{Y}$, Iwata $\mathrm{K}$, Yamada S, Inoue K, Ohtaki T, Matsumoto H, Maeda K: Involvement of central metastin in the regulation of preovulatory luteinizing hormone surge and estrous cyclicity in female rats. Endocrinology 2005; 146:4431-4436.

48 D’Anglemont de Tassigny X, Fagg LA, Carlton $\mathrm{MB}$, Colledge WH: Kisspeptin can stimulate gonadotropin-releasing hormone $(\mathrm{GnRH})$ release by a direct action at $\mathrm{GnRH}$ nerve terminals. Endocrinology 2008; 149: 3926-3932.

49 Luque RM, Cordoba-Chacon J, Gahete MD, Navarro VM, Tena-Sempere M, Kineman RD, Castano JP: Kisspeptin regulates gonadotroph and somatotroph function in nonhuman primate pituitary via common and distinct signaling mechanisms. Endocrinology 2011;152:957-966.

50 Lehman MN, Robinson JE, Karsch FJ, Silverman AJ: Immunocytochemical localization of luteinizing hormone-releasing hormone pathways in the sheep brain during anestrus and the mid-luteal phase of the estrous cycle. J Comp Neurol 1986;244:19-35.

51 Polkowska J, Dubois MP, Domanski E: Immunocytochemistry of luteinizing hormone-releasing hormone in the sheep hypothalamus during various reproductive stages: correlation with the gonadotropic hormones of the pituitary. Cell Tissue Res 1980;208:327-341.

- 52 Boukhliq R, Goodman RL, Berriman SJ, Adrian B, Lehman MN: A subset of gonadotropin-releasing hormone neurons in the ovine medial basal hypothalamus is activated during increased pulsatile luteinizing hormone secretion. Endocrinology 1999; 140:5929-5936. 